\title{
Analysis of The Characters' Concern of The Natural Environmental Problems in Japanase Animation Miyori no Mori Directed by Nizo Yamamoto
}

\author{
Budi Mulyadi ${ }^{1}$ Yuliani Rahmah ${ }^{2}$ Fajria Noviana $^{3}$ \\ ${ }^{1}$ Faculty of Humanities, Diponegoro University
}

\begin{abstract}
Currently, many literary works discuss environmental problems. Animation is a modern literary work that often discusses environmental issues. One of which is an animation by director Nizo Yamamoto entitled Miyori no Mori. This animation is full of criticism related to environmental issues. Through literary ecocritical research methodology, this study discusses the problems of the natural environment and the manifestations of the characters' concern for the natural environment to save the natural environment. From the research results, it is known that the main problems in this animation are: the efforts of evil humans who want to drown the forest and the village where the main character lives into a dam. The forest located near this village is the source of life for the surrounding community. With various efforts made, the main character struggled to thwart the government's efforts to sink forests and villages. The efforts made by the characters in this animation are a manifestation of their concern in protecting and protecting the natural environment from the damage caused by evil humans who want to submerge forests and their surrounding areas into the dam.
\end{abstract}

\section{Introduction}

Literary work is a reflection of the environment. Literary works are a place to express the thing that occurs in nature. Nature must be treated as best as possible because nature is an important part of human life. Humans need nature for growth and development and vice versa. Nature needs humans to care for it and take care of it [1].

So far, many people think that literature is only concerned with and contains social, psychological, religious, and educational problems. Many people do not know that literature can be connected with environmental problems. Nowadays, many literary creators are aware of the importance of preserving and protecting the environment. In creating a literary work, they raise environmental issues in which it is full of moral messages about the importance and value of the environment to always be preserved and preserved to be sustainable.

Endraswara, in his book, states that concern and sensitivity to the environment must be articulated by anyone with any background, including in the field of literature. Perhaps the literary field is at the forefront of voicing concern for nature conservation [2]. 
Concern and sensitivity of the creators of works towards the environment recently can be felt by the increasing number of literary works that take themes or issues about the environment. One of the literary works with environmental themes is the Japanese animation entitled Miyori no Mori by director Nizo Yamamoto which was produced in 2007 [3].

Animation Miyori no Mori tells the story of the struggle of a 10-year-old elementary school girl named Miyori who tries to save the forest near Komori village where she was entrusted by her parents who live in Tokyo. The forest that supports the village of Komori, where there are still many wild animals and spirits who guard the forest, is planned to be drowned by a company in Tokyo and will be made a dam. Teamed up with her new friends at Elementary School and a forest guard spirit who has chosen herself to be a forest ranger, Miyori tries her best to prevent the efforts of those from the company who want to submerge the forest into the dam.

When talking about the preservation of the environment, the main emphasis lies on the attempt to ensure - excluding unpredictable large-scale natural catastrophes - those unlimited natural resources, such as sunlight, air or water, remain unlimited, and on the use of limited natural resources in a way that would provide that those resources remain available for future generations. In most cases, the major obstacle towards sustainable development is a conflict between economic and environmental considerations, whereby in most cases, the former outweigh the latter [4].

The conflict between economic and environmental considerations is clearly illustrated in this anime. The people of Tokyo city want to build a dam for personal gain at the expense of the surrounding environment. This animation is very thick with environmental themes. The moral message about the importance of protecting and loving the environment was felt from the beginning to the end of the story. There are many criticisms conveyed in this animation regarding human selfishness in destroying the environment without paying attention to the ecology in it, which is related to environmental sustainability and the creatures in it.

Animation, which is part of many literary works, features themes about nature. The relationship between nature and literature raises a concept about ecological problems in literature among literary critics. The term ecocriticism (ecocriticism) is used as a term regarding the concept of literary criticism relating to nature and the environment. According to Harsono, the term eco-critic comes from English ecocriticism which is a formation of the word ecology and the word critic. Ecology can be defined as a scientific study of the patterns of relationships, plants, animals, and humans to one another and their environment [5].

Endraswara, in his book, explains, meanwhile, that eco-centrism as the foundation for ecocritical existentialist theory holds that humans and their natural origins have consistency and dependence to create harmony and health in the human mind to create sustainability and maintenance. However, in its development to fulfil personal survival as well as the needs of joint development, humans often make changes to nature. This results in the loss of natural species, deterioration of the quality of nature, and even threatens the sustainability and harmony of human life itself [6].

What Endraswara described above is reflected in the plot of the anime Miyori no Mori. There is a group of people from a company who are trying to make a change in nature because of the ambition for material gain. They try to destroy the forest, which is the source of life for local people and is home to various kinds of animals and plants, including one of the rare animals protected by the Japanese government, namely the golden eagle. The efforts of this evil human, of course, met with resistance from residents, including the main character in the animation. The characters in this animation care about the natural environment around them. They will not allow anyone to destroy the environment around them. 
In this paper, by using ecocritical theory, researchers will try to analyze the kind of concern shown by the characters in this animation for the natural environment around them and what efforts they make to prevent damage to the natural environment due to the construction of a dam in their area of residence.

One of the things discussed in the literature ecocritical is about environmental management. In managing the environment, humans must pay attention to applied ethics. Without a type of ethics (rights and responsibility theory) and a theory of values, humans will lack guidance and direction to deal with problems, whether they are global, environmental, or otherwise [7]. Najmuddin explained that environmental ethics is a human moral policy in dealing with the environment [8]. Keraf explains that there are several forms of environmental, ethical principles, including Respect for Nature, Attitude of Responsibility, Moral Response to Nature, Attitude of Solidarity to Nature, and Attitude of Compassion and Care for Nature [9]. The principles of environmental ethics that are part of literary eco-critic will serve as a basis for analyzing the character's care for the natural environment in the animation Miyori no Mori by director Nizo Yamamoto.

\section{Research Method}

The method used in this paper is the descriptive analytical method. This study uses an ecocritical approach that focuses on the form of environmental, ethical principles which cover Respect for Nature, Attitude of Responsibility, Moral Response to Nature, Attitude of Solidarity to Nature, and Attitude of Compassion and Cares for Nature. This type of research is qualitative. The data source in this study is the animation Miyori no Mori by Director Nizo Yamamoto. The data analysis was carried out by investigating environmental problems that occurred in this animation as well as matters relating to the form of concern of the characters in the animation towards the natural environment. The data were then analyzed and interpreted. After that, the data is presented in the form of a description, then it is concluded.

\section{Result and Discussion}

\subsection{Environmental Problems in Animation Miyori no Mori by director Nizo Yamamoto}

Animation Miyori no Mori is an animation in which it discusses the importance of protecting the environment to exist and avoid the damage done by humans who want to destroy the environment for their interests. The director of this animation, Nizo Yamamoto, tries to convey a moral message about the importance of protecting and defending the natural environment from the ambitions of evil humans who want to destroy nature. Through the characters in this animation. Director Nizo Yamamoto has widely criticized the damage to the natural environment caused by humans who have the ambition to take material benefits by exploring and destroying nature. One of the criticisms related to the environment conveyed in this anime is a statement conveyed by one of the characters in this anime, the ghost guarding the springs in the forest. The ghost satirized human behavior that likes to destroy the environment in the following quote below.

"This clean water. This place will soon be destroyed because it will be drowned. After all, a dam will be built. All of these areas will become dams. Why do humans have the heart to destroy important things? Humans are really stupid creatures "

This statement was conveyed by the forest guardian ghost to the main character named Miyori as a form of the ghost's concern and hatred for humans who like to destroy nature. 
This animation is full of environmental elements. The setting of this animation is a village called Komori. Near the village, there is a forest where various kinds of living things live, both in the form of flora, fauna, and astral creatures who are guardians of the forest. This forest is also home to one of the endangered animals protected by the Japanese state, the golden eagle.

This forest is also a source of life for residents. The local people make medicines from the plants that grow in the forest. In addition, the residents also make household utensils such as chairs, beds, and others using the wood that grows in the forest. There are several scenes in this anime that depict local people who use the forest as a source of life.

The peaceful village suddenly got into trouble when some bad guys from the city came to the village to investigate the dam construction in the area. This is very unsettling for the local community because with the construction of a dam in the area, the forest and the area where they live will be drowned and the villagers have to move to another place. In addition, by sinking the forest, there will be damage to the ecosystem. The animals in the forest will drown. This is a natural environmental problem that occurs in this animation. Knowing that the forest and village will be drowned and turned into a dam, the main character named Miyori teamed up with her friends and forest ranger creatures to prevent the dam construction plan. Miyori does not want to see the forest as the source of life for the surrounding community, where animals and plants live, and as a source of water for the surrounding community being destroyed and made into a dam. The following is one of the expressions made by Miyori as a protest against the dam construction. This expression can be seen in the following sentence excerpt.

"Aren't humans the enemy who will build a dam? Humans are selfish creatures. " Miyori's remarks were conveyed as a form of protest against the selfishness of humans who arbitrarily destroy nature for the benefit of certain groups. Building a dam, if it is done in a proper place and does not sacrifice the surrounding environment, is not a problem. It is a good thing because dams are very useful for irrigation, main water supply, power generation, flood control, fisheries, tourism, and water sports. In this animation, the construction of the dam will sacrifice many things, one of which will be to drown the forest, where the local people live, as well as where animals live, including one of Japan's rare animals that are protected by the state. This is a problem and raises resistance from the surrounding community to prevent the construction of the dam.

Director Nizo Yamamoto, through his anime, criticizes human selfishness, who likes to destroy and destroy the natural environment for personal or group gain.

From the results of the analysis, there are two problems related to the natural environment contained in this animation Miyori no Mori. The two problems are.

1. There are attempts by evil humans to destroy the forest and its surroundings to be used as dams for the interests of certain groups. With the construction of the dam, it will destroy the forest which is a source of water and a place to live for animals and one of the endangered species that are protected by the state,

2. There was an attempt to destroy one of the rare animals in Japan, namely the golden eagle that lives in the forest for the sake of smooth construction of the dam.

To overcome this problem, there are efforts made by the characters in this anime to save the forest and birds that are protected by the state from extinction. This business effort is a form of concern for the leaders of the environmental problems that occur around them. One of the efforts made by the characters in this animation is that they work together to formulate a dam prevention strategy. Their first strategy was to find a golden eagle in the forest. Some laws prohibit large-scale development in forests or mountains where there are rare species, as conveyed by Daisuke, one of the characters in this animation to his friends.

"Only 500 of them are left in Japan. Here it is written that the golden eagle used to live here. Some laws prohibit large developments in forests with endangered species " 
Another strategy taken by the characters in this animation is to work together to get rid of the people who are going to build the dam. Miyori, as the main character in this animation, collaborates with the forest guardian spirits in a way that the forest guardians are told to show their form to people who enter the forest, to frighten and drive these people out of the forest.

Meanwhile, village children were in charge of keeping people from the forest from escaping to the city. The village children reported this to village officials and the police about the behaviour of people from the company who were going to kill the golden eagle so that the dam could be built.

The effort was successful, people from the company who were going to hunt and kill the golden eagle were taken to the police officers, and finally, the dam was cancelled so that the forest and the surrounding area were not drowned.

\subsection{The Form of The Character's Concern for Nature}

Concern for nature can be manifested in several forms of environmental, ethical principles, including Respect for Nature, Attitude of Moral Responsibility towards Nature, Attitude of Solidarity with Nature, and Attitude of Compassion and Care for Nature. The following is an analysis of the character's concern for nature depicted in the animation Miyori no Mori.

1. Respect for nature.

The respect for nature, according to Keraf is integrated into (1) the ability to respect nature, (2) the awareness that nature has a value in itself, (3) the awareness that nature has the right to be respected, (4) Nature has integrity, and (5) respect for nature to live, live, grow and develop naturally by the purpose of its creation. Respect for nature is shown in the form of respect for nature carried out by residents [10]. The real form of respect for nature shown by the characters in this anime is by living in harmony with nature. They do not want to disturb or destroy the ecology of the forest by cutting down trees arbitrarily or by hunting animals that live in the forest. The following are some of the remarks conveyed by several figures in this animation that have something to do with respect for nature.

"Humans decide whether forests live or die. You should be able to hear the voices of the forest creatures."

This statement was conveyed by the grandmother to Miyori so that Miyori appreciates all types of creatures in the forest ranging from plants, trees, animals, and all the ecosystems that exist in the forest.

2. The attitude of moral responsibility towards nature

Apart from respecting nature, humans are also required to jointly take concrete actions in protecting the environment. Humans who live and live on this earth have a responsibility for the preservation and destruction of nature, not just an individual burden. This form of responsibility is to remind, prohibit, and punish anyone who deliberately destroys and endangers nature [11].

One of the forms of moral responsibility shown by the characters in this animation is by trying to save the forest from the efforts of evil humans who want to drown the forest and become a dam for the benefit of certain groups.

The real form of an attitude of moral responsibility towards nature is in the form of:

a. Reminds evil humans who will drown the forest and all its contents for the sake of dam users.

Following is the warning was given by the main character Miyori to people who are about to drown in the forest. 
"I know your plan. The company sent you to prevent the blocking of the dam that was planned to be built here, right. If you love your life, leave this forest."

The remarks above are Miyori's warning to these bad people not to continue her intention to build a dam in this forest.

b. Punish bad people who will drown the forest and all its contents for the sake of building the dam.

Miyori, the main character in this animation, along with all forest-guarding spirits, punish them by frightening them by showing their true forms to bad people in the forest so that they stop their efforts to drown the forest. The people saw many terrifying figures in the forest, they were very scared and ran away from the forest.

The police and villagers also punished them by interrogating them after they were caught on the outskirts of the forest.

"Why are you sneaking in the forest with rifles?" why are you hunting when it's not hunting season now? Come with us to the office and explain everything to us. I won't make you bear food if you explain it honestly."

After being interrogated, the bad guys were brought to a police actor for trial. It is a form of punishment for those who try to destroy nature.

3. Solidarity toward nature

An attitude of solidarity towards nature is integrated into (1) an attitude of sharing what nature feels; (2) efforts to save nature, prevent humans from damaging and polluting nature and its ecosystem; and (3) efforts to align human behavior and ecosystems [12].

As explained by Keraf above, one form of natural solidarity is an effort to save and prevent humans from destroying nature and the ecosystem in it. Efforts to save nature from damage caused by humans are the main theme in this animation. The forest and the ecosystem in it will be destroyed and drowned by people from Tokyo for the sake of a company. The plan to sink this forest becomes a serious problem for the villagers because this forest is a source of life for them, so they try to save the forest from the drowning plan. Efforts to save forests are a concrete form of solidarity with nature. One of the ways that the forest can survive drowning is by finding a rare bird protected by Japan, namely the golden eagle. forest.

The following is a quote that describes the main character Miyori's efforts to save the

"Everyone knows that this forest will soon sink and become a dam, but there is still hope to stop it. Find the golden eagle. They won't be able to build a dam if there's a golden eagle here."

This statement was conveyed by Miyori to her friends who also wanted to save the forest from damage. And this is a concrete manifestation of the solidarity attitude towards nature shown by the characters in this animation.

4. An attitude of love and concern for nature

Sukmawan concludes that human affection and care for nature is realized by the awareness that (1) all living things have the right to be protected, maintained, not harmed; and (2) protect and protect all living beings without expecting anything in return [13].

As explained by Sukmawan above, one form of compassion and concern for nature is to have the principle that all living things have the right to be protected, cared for, not harmed.

This principle is owned by the main characters in this animation. They believe that protecting and not hurting living things is the duty of everyone so that when they know the 
forest in which there are many living things, they will be drowned and made into a dam, making the characters feel anxious and at the same time feel sorry for the living creatures in the forest. So they made various efforts to prevent the dam's construction.

The following quotes describe an attitude of love and care for nature.

"We will kick them out again, no matter when they will come again"

"Being a forest ranger is not bad". "If you are with me, i can protect this forest ".

The above quote was pronounced by Miyori, the main character in this anime where she was asked by the forest dwellers to become a forest ranger so that the existence of the forest is always awake and secure and safe from the disturbance of people who want to destroy it.

Rahmah in her paper writes the preservation of nature and the environment is one of the positive attitudes of Japanese people that must be emulated by the nations and the world [14]. The concern for the natural environment shown by the characters in this animation as explained above is a reflection of one of the positive attitudes of the Japanese people in protecting the natural environment.

Japan is one of the countries in the world in which technology has been rapidly progressing and able to create things that were unthinkable in human civilization before. Their sophisticated technology developed into a global commodity that expanded throughout the world, making the country one of the countries whose existence has been known to the wide world. But behind its existence as a developed country, a modernization that developed in that country also had negative impacts on humans' lives [15].

The dam construction plan using the advanced technology described in this animation turns out to be less beneficial for the surrounding community and even has a negative impact because the dam construction plan will result in the forest and village where the people live will be drowned. However, thanks to the concern of the characters in this anime for nature and the efforts of the characters to prevent the construction of this dam, the plan to build this dam was cancelled.

\section{Conclusion}

Animation Miyori no Mori is full of moral messages about the importance of protecting nature and the environment from damage either caused by society or people who want to take advantage of the destruction of nature. Japan is one of the countries that maintain the preservation of the natural environment, but even so, there are still humans who try to destroy the environment for material gain. In this animation, the director wants to give a very deep message about the importance of preserving nature and the environment. The efforts made by the characters in this anime to save the forest and surrounding areas from being destroyed due to the construction of a dam is a form of the director's hope that the audience of this anime can do the same thing if the environment around them wants to damage or destroy it. Meanwhile, people from Tokyo who are trying to build Dam at the expense of the forest and surrounding areas depicted in this animation are indirect criticism from the director to people who do not care about nature, don't do anything that can destroy nature because they will get good punishment from them. Nature itself as well as from the local community and government. The concern for the environment shown by the characters in the animation is expected to be an example that we as humans must have a sense of care and empathy for nature because we live in nature. We should always try to protect and improve the environment from damage done by irresponsible people, as depicted in this animation. 


\section{References}

1. K. Purwati, Analisis Kepedulian Tokoh terhadap lIngkungan Alam dalam Novel Sumur Minyak Air Mata Karya Winendra Gunawan. Jurnal Estetika, (1), 56 (2014)

2. S. Endraswara, Ekologi sastra, (CAPS Yogyakarta, 2016)

3. Nippon Animation. Fuji TV. (Producer). Miyori no Mori. [Televition Broadcast], Tokyo, (2007)

4. E. Gordeeva, Environmental policy in a changing world, Published in the Slovak Republic International Journal of Environmental Problems. Slovak Republic, (2017)

5. Harsono, Ekokritik: Kritik sastra berwawasan lingkungan, Ejurnal Undip (2008)

6. S. Endraswara, Ekologi sastra, (CAPS Yogyakarta, 2016)

7. R. Attfield, Etika Lingkungan Global, (Kreasi Wacana Bantul, 2010)

8. R. Nadjmuddin, Membangun Lingkungan Hidup yang Harmonis \& Berperadaban. (Grafindo Khazanah Jakarta, 2005)

9. A. Keraf, Etika Lingkungan, (Kompas Media Nusantara Jakarta, 2010)

10. A. Keraf, Etika Lingkungan, (Kompas Media Nusantara Jakarta, 2010)

11. A. Keraf, Etika Lingkungan, (Kompas Media Nusantara Jakarta, 2010)

12. A. Keraf, Etika lingkungan, (Kompas Media Nusantara Jakarta, 2010)

13. S. Sukmawan, Ekokritik Sastra: Menanggap Sasmita Arcadia, (UB Press Malang, 2016)

14. Y. Rahmah, ENIS Omamori: Harmonization of Humans and Their Environment in Cultural Symbols in Proceedings of the $5^{\text {th }}$ International Conferenceon Energy, environmental and Information System (ICENIS), Semarang, Indonesia, (2020)

15. Y. Rahmah, ENIS Muen Shakai: The Fading of Traditional Values Amidst Modernization of Japanese Society in Proceedings of the $5^{\text {th }}$ International Conferenceon Energy, environmental and Information System (ICENIS), Semarang, Indonesia, (2020) 